\title{
The $F_{1} F_{0}-A T P a s e$ of Escherichia coli
}

\author{
Substitution of proline by leucine at position 64 in the c-subunit causes loss of oxidative phosphorylation
}

\author{
Anthony L. FIMMEL, David A. JANS, Lyndall LANGMAN, Lewis B. JAMES, Greg R. ASH, \\ J. Allan DOWNIE, Alan E. SENIOR, † Frank GIBSON and Graeme B. COX \\ Department of Biochemistry, John Curtin School of Medical Research, Australian National University, \\ Canberra, A.C.T., Australia
}

(Received 10 March 1983/Accepted 27 April 1983)

\begin{abstract}
The uncE410 allele differs from the normal $u n c E$ gene in that $\mathrm{C} \rightarrow \mathrm{T}$ base changes occur at nucleotides 190 and 191 , resulting in proline at position 64 in the $c$-subunit of the $F_{1} F_{0}$-ATPase being replaced by leucine. Two partial-revertant strains were isolated in which alanine-20 of the $c$-subunit was replaced by proline, owing to a $\mathrm{G} \rightarrow \mathrm{C}$ base change at nucleotide 58. These c-subunits, coded for by the uncE501 and uncE502 alleles, therefore contained two amino acid changes, namely proline-64 $\rightarrow$ leucine, and alanine-20 $\rightarrow$ proline. Membranes prepared from the partial-revertant strains lacked ATP-dependent atebrin-fluorescence-quenching activity but were able to carry out oxidative phosphorylation. The ATPase activity of the $\mathrm{F}_{1}$-ATPase was inhibited when bound to membranes from strains carrying the uncE410, uncE501 and uncE502 alleles. It is concluded that a bend in the helix axis in one of the arms of the $c$-subunit hairpin structure is required for integration of the $c$-subunit into a functional $F_{1} F_{0}-A T P a s e$.
\end{abstract}

The genes forming the unc operon in Escherichia coli code for the components of the energy-coupling ATPase complex and map at about $82.5 \mathrm{~min}$ on the $E$. coli chromosome (Downie et al., 1979a). The $u n c E$ gene, the third gene from the promoter end of the unc operon (Gay \& Walker, 1981), codes for the DCCD-binding protein or $c$-subunit of the $F_{1} F_{0}$ ATPase (Downie et al., 1981). Six mutations in the uncE gene have been described for which the resulting amino acid substitutions in the mutant $c$-subunits have been established. Mutations which resulted in isoleucine- 28 being replaced by either valine or threonine have been shown to cause a loss of reactivity of aspartic acid-61 with the inhibitor DCCD (Hoppe et al., 1980a). It was concluded that the $c$-subunit formed a hairpin structure such that isoleucine-28 was near to aspartic acid-61. Mutations resulting in aspartic acid-61 being re-

Abbreviations used: ATPase, $\mathbf{M g}^{2+}$-stimulated adenosine triphosphatase; DCCD, dicyclohexylcarbodiimide.

* Present address: Department of Genetics, The John Innes Institute, Colney Lane, Norwich, U.K.

$\dagger$ Present address: Department of Biochemistry, University of Rochester Medical Center, School of Medicine and Dentistry, Rochester, NY, U.S.A.

$\ddagger$ To whom correspondence and requests for reprints should be directed. placed by either glycine or asparagine have confirmed that this amino acid plays a key role in proton translocation and oxidative phosphorylation (Hoppe et al., 1980b, 1982; Wachter et al., 1980). The substitutions of glycine-23 by aspartic acid and of leucine- 31 by phenylalanine prevent the incorporation of the mutant $c$-subunits into the membrane, although in the latter case assembly does occur if the gene dosage is increased (Jans et al., 1983).

The amino acid substitutions in the $c$-subunits coded for by the uncE410, uncE501 and UncE502 alleles and their effects on assembly and function of the $F_{1} F_{0}-A T P a s e$ are the subject of the present paper.

\section{Materials and methods}

\section{Enzymes and chemicals}

Restriction endonucleases and virus-T4 DNAligase were obtained from Boehringer Mannheim Australia Pty. Ltd. All chemicals used were of the highest quality available.

\section{Bacterial strains and plasmids}

All of the bacterial strains used were derived from $E$. coli $\mathrm{K} 12$ and are described, together with the plasmids used, in Table 1. 


\section{Genetic techniques}

The techniques used for genetic experiments were as outlined previously (Downie et al., 1980; Gibson et al., 1977b; Gibson et al., 1978).

\section{Preparation of plasmids}

Plasmid DNA was prepared as described by Selker et al. (1977). Chromosomal DNA was prepared by the phenol-extraction method of Saito \& Miura (1963).

\section{DNA sequencing}

Nucleotide sequences were determined by the method of Maxam \& Gilbert (1980). End-labelling of DNA was carried out by using DNA polymerase and $\left[\alpha^{-32} \mathrm{P}\right]$ deoxyadenosine triphosphate (Maxam \& Gilbert, 1980).

\section{Purification of the $c$-subunit of the $F_{1} F_{0}-A T$ Pase}

The $c$-subunit of the $F_{1} F_{0}$-ATPase was purified from chloroform/methanol extracts (Fillingame, 1976) of membranes (about $6 \mathrm{~g}$ of membrane protein) by chromatography on CM-cellulose (Graf \& Sebald, 1978; Hoppe et al., 1980a).

\section{Amino acid analysis}

Peptides were hydrolysed in $6 \mathrm{M}-\mathrm{HCl}$ at $100^{\circ} \mathrm{C}$ for $22 \mathrm{~h}$. Amino acid analysis was carried out by using a Beckman System 6300 high-performance analyser.

\section{$\mathrm{CNBr}$ treatment and peptide purification}

The purified $c$-subunit was cleaved by $\mathrm{CNBr}$ and the peptides purified as described by Jans et al. (1983).

\section{Media and growth of organisms}

The mineral-salts minimal medium used and additions were as described previously (Gibson et al., 1977b). Cells for the preparation of membranes were grown in 14-litre fermenters essentially as described previously (Cox et al., 1970). The media in the fermenter vessels was supplemented with 5\% (v/v) Luria broth (Luria \& Burrous, 1957). Growth yields were measured as described previously (Cox et al., 1970). Turbidities of cultures were measured with a Klett-Summerson colorimeter.

\section{Preparation of cell membranes}

The preparation and treatment of membranes were as described previously (Cox et al., 1983).

\section{ATPase activity}

ATPase activity was measured by using the method described by Gibson et al. (1977a).

\section{Atebrin-fluorescence quenching}

Atebrin-fluorescence quenching was measured as described by Gibson et al. (1977a).

Table 1. Bacterial strains and plasmids used

The chromosomal gene nomenclature is that given by Bachmann et al. (1976); plasmid nomenclature is that given by Novick et al. (1976).

Strain no. Relevant genotype

(a) Bacterial strains

AN1006 pAN14, uncE410/argH ilvC pyrE purE recA

$\begin{array}{ll}\text { AN1521 } & \text { uncF476 argH pyrE entA recA } \\ \text { AN1440 } & \text { uncF469 argH pyrE entA recA } \\ \text { AN955 } & \text { uncE410 argH pyrE entA } \\ \text { AN1782 } & \text { argH pyrE entA }\end{array}$

AN1781 uncE501 argH pyrE entA

AN1892 UncE502 argH pyrE entA

AN1707 uncF476 thr leu $r k^{-} m k^{+}$recA

AN1959

AN1971

(b) Plasmids

pAN14 PyrE ${ }^{+}$uncE410 ilv $\mathrm{C}^{+} \operatorname{argH}^{+}$

pHC79 $A p^{\mathrm{r}} T c^{\mathrm{r}}$

pAN175 $A p^{\mathrm{r}} T c^{\mathrm{s}} u n c B^{+} E 501 F^{+} H^{+} A^{+}$

pAN177 $A p^{\mathrm{r}} T c^{\mathrm{s}}$ unc $B^{+} E 502 F^{+} H^{+} A^{+}$
Notes and references

Partial diploid strain carrying uncE410 allele on $\mathrm{F}^{\prime}$ plasmid (prepared as described previously; Gibson et al., 1977b)

Downie et al. (1981)

Downie et al. (1981)

Downie et al. (1979b)

U.v.-induced revertant of AN955 (The present paper)

U.v.-induced partial revertant of AN955 (The present paper)

U.v. partial revertant of AN955 (The present paper)

Obtained by transducing uncF476 allele into $\mathrm{C} 600$ background

pAN175, uncE501/uncF476 thr leu rk $k^{-} k^{+}$recA The present paper pAN177, uncE502/uncF476 thr leu rk- $m k^{+}$recA The present paper

$\mathrm{F}^{\prime}$ plasmid carrying uncE410 allele (prepared as described previously; Gibson et al., 1977b)

pBR322 derivative obtained from $\mathrm{Dr}$. B. Hohn, (Friedrich Miescher Institute, Basel, Switzerland)

pHC79 derivative carrying uncE501 allele (The present paper)

pHC79 derivative carrying uncE502 allele (The present paper) 


\section{Oxidative phosphorylation}

Oxidative phosphorylation was measured as described by Cox et al. (1973).

\section{Protein determination}

Protein concentrations were determined by using Folin's phenol reagent (Lowry et al., 1951), with bovine serum albumin (fraction V, Sigma) as standard.

\section{Results}

\section{Further investigation of the unc-410 allele}

The unc-410 allele had, on the basis of geneticcomplementation data and on the failure to isolate revertants, been previously thought to affect a gene or genes in addition to the $u n c E$ gene (Downie et al., 1979b). The mutant strain carrying the unc-410 allele had been isolated after u.v. mutagenesis, and it was suggested that a deletion involving the $u n c E$ gene and an unknown adjacent gene had occurred. The $u n c F$ gene is the gene immediately after the UncE gene (Gay \& Walker, 1981) and the uncF469 and uncF476 alleles (Downie et al., 1981) had not been described at the time the previous work with the unc-410 allele was published. The partial-diploid strain AN1006 carries the unc-410 allele on an F-plasmid (pAN14) and was used as a donor strain in complementation tests with the female strains AN1521 (uncF476) and AN1440 (uncF469). Complementation was obtained since colonies were formed on the succinate medium in the region where the donor and recipient strains mixed in the cross-streaking test described previously (Gibson et al., 1977a). The reverse cross, in which either unc $F$ mutant allele was on the plasmid and the unc-410 allele on the chromosome, also gave complementation. The unc-410 mutation does not, therefore, affect the $u n c F$ gene.

The medium used previously (Downie et al., $1979 b$ ) in the attempted isolation of revertants was a succinate/minimal medium. In a further attempt, cells of strain AN955 (unc-410) were spread on solid succinate/minimal medium supplemented with $0.05 \%$ casamino acids and irradiated with u.v. light for $40 \mathrm{~s}$. Under these conditions revertant colonies were obtained. However, of about 50 revertant colonies examined only one, strain AN1782, was found to be a full revertant (see below). Of the remaining partial revertants, two were selected (AN1781 and AN1892) for further examination. Strains AN1781 and AN1892 represented the group of partial-revertant strains giving growth yields closest to that obtained for a normal strain (see below).
Amino acid substitutions in the c-subunits of the $F_{1} F_{0}-A T P a s e s$ from strain AN955 (unc-410) and the revertant strains $A N 1782, A N 1781$ and $A N 1892$

The $c$-subunits of the $\mathrm{F}_{1} \mathrm{~F}_{0}-\mathrm{ATPase}$ were extracted from membranes of strains AN955 (unc-410), AN1782, AN1781 and AN1892 and purified by chromatography on CM-cellulose. The purified proteins were solubilized in formic acid and cleaved with $\mathrm{CNBr}$. Cleavage of the $c$-subunit with $\mathrm{CNBr}$ produces nine fragments (Fig. 1). The peptide fragments soluble in $0.1 \%$ phosphoric acid were separated from insoluble material by centrifugation and examined by high-pressure liquid chromatography. The elution profiles obtained by measurement of $A_{210}$ indicated that fragment B7 of the $c$-subunit from strain AN1782 was different from the B7 fragments from strains AN955 (unc-410), AN1781 and AN1892 (Fig. 2). The eluate corresponding to each of the peaks of absorption was collected, freeze-dried and the amino acid compositions determined. Fragment B7 derived from strains AN955 (unc-410), AN1781 and AN1892 contained two leucine residues and no proline residues, whereas B7 derived from strain AN1782 had the expected one leucine residue and one proline residue (Table 2 ). The amino acid compositions of the remaining soluble fragments derived from all four strains were the same (L. B. James, unpublished work).

The material insoluble in $0.1 \%$ phosphoric acid was dissolved in chloroform/methanol $(1 / 1, v / v)$ and the B6 fragments purified by cellulose t.l.c. Amino acid analysis indicated that the B6 fragments from strains AN1781 and AN1892 contained one less alanine residue and one more proline residue than the B6 fragments from strains AN955 (unc-410) and AN1782 (Table 2).

It was concluded that the unc-410 mutation occurs in the $u n c E$ gene and that the partialrevertant strains AN1781 and AN1892 each carry a second mutation in the $u n c E$ gene. The mutant $u n c E$ genes present in strains AN1781 and AN1892 result in the formation of $c$-subunits with two amino acid changes and have been given the allele numbers uncE501 and UncE502 respectively. The $c$-subunit from strain AN1782 appeared to be normal.

\section{Cloning and sequencing of the uncE501 and uncE502 alleles}

In order to locate which alanine residue has been replaced by proline in the $\mathrm{B} 6$ fragments derived from strains AN1781 (uncE501) and AN1892 (uncE502), the DNA coding for the mutant csubunits was sequenced and compared with the DNA sequence for a normal $u n c E$ gene.

Chromosomal DNA was prepared from strains AN1781 (uncE501) and AN1892 (uncE502) and digested with the restriction endonuclease HindIII. 
$5^{\prime}$ ATG GAA AAC CTG AAT ATG GAT CTG CTG TAC ATG GCT GCC GCT GTg ATg ATg GGT CTG GCG Met Glu Asn Leu Asn Met Asp Leu Leu Tyr Met Ala Ala Ala Val Met Met Gly Leu Ala

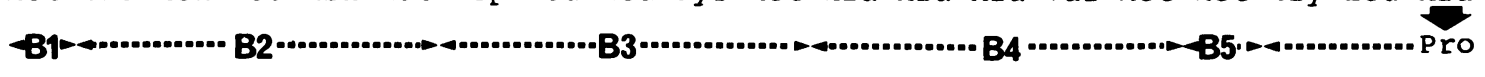

GCA ATC GGT GCT GCG ATC GGT ATC GGC ATC CTC GGG GGT AAA TTC TTG GAA GGC GCA GCG Ala Ile Gly Ala Ala Ile Gly Ile Gly Ile Leu Gly Gly Lys Phe Leu Glu Gly Ala Ala

240
GAT GCT ATC CCG .ATG ATC GCT GTA GGT CTG GGT CTG TAC GTG ATG TTC GCT GTC GCG TAG
Asp Ala Ile Pro Met Ile Ala Val Gly Leu Gly Leu Tyr Val Met Phe Ala Val Ala end

Fig. 1. Nucleotide sequence of the DNA coding for the c-subunit of the $F_{1} F_{0}-A T P a s e$ of $E$. coli together with the corresponding amino acid sequence

The fragments of the $c$-subunit generated by $\mathrm{CNBr}$ are indicated, and the designation of the fragments (B1 to $\mathrm{B} 9$ ) follows that used by Wachter et al. (1980). The base changes and the corresponding amino acid change due to the uncE410 allele (proline-64 $\rightarrow$ leucine) are indicated as are the additional changes due to the uncE501 and uncE502 alleles (alanine- $20 \rightarrow$ proline).

Each of the DNA preparations were mixed with HindIII-digested pHC79-plasmid DNA and treated with virus-T4 DNA-ligase. Strain AN1707 (uncF476, recA) was then transformed with each of the ligated-DNA mixtures and selection made for growth on succinate/ampicillin minimal medium. One colony was selected from each of the transformation experiments, purified, and each strain shown to carry a plasmid with an insert corresponding in size to that of pAN51 (Downie et al., 1980). Strain AN1959 carried the plasmid pAN175 with an insert derived from the chromosomal DNA of strain AN1781 (uncE501). Strain AN1971 carried the plasmid pAN177 with an insert derived from the chromosomal DNA of strain AN1892 (uncE502).

The Hinf1- and BamH1-restriction-endonuclease-generated DNA fragments of plasmids pAN175 and pAN177 were used to derive the nucleotide sequences of the UncE501 and uncE502 alleles, respectively, as described previously (Jans et al., 1983). The uncE501 and uncE502 mutant DNA sequences were identical and differed from the normal sequence in that $\mathrm{C} \rightarrow \mathrm{T}$ base changes occurred at nucleotides 190 and 191 and a $G \rightarrow C$ base change occurred at nucleotide 58 (see Fig. 1). The changes at nucleotides 190 and 191 result in proline being replaced by leucine at position 64 and the change at nucleotide 58 results in alanine being replaced by proline at position 20 (see Fig. 1).

Effect of the uncE501 and UncE502 mutant csubunits on the function of the $F_{1} F_{0}$-ATPase

The growth yields of strains AN1781 (uncE501) and AN1892 (uncE502) on limiting concentrations of glucose were determined and compared with those obtained for the original mutant strain AN955 (uncE410) and the full-revertant strain AN1782 $\left(u n c^{+}\right)$(Table 3). Strain AN1782 $\left(u n c^{+}\right)$gave a value expected for a normal strain (Cox \& Gibson, 1974), whereas strains AN1781 (uncE501) and AN1892 (uncE502) gave values intermediate between those of the mutant strain AN955 (uncE410) and strain AN1782 (unc $\left.c^{+}\right)$.

Membranes were prepared from strains AN955 (uncE410), AN1782 (unc $c^{+}$), AN1781 (uncE501) and AN1892 (uncE502) and ATPase activities, fluorescence-quenching activities and oxidativephosphorylation activities examined. The ATPase 

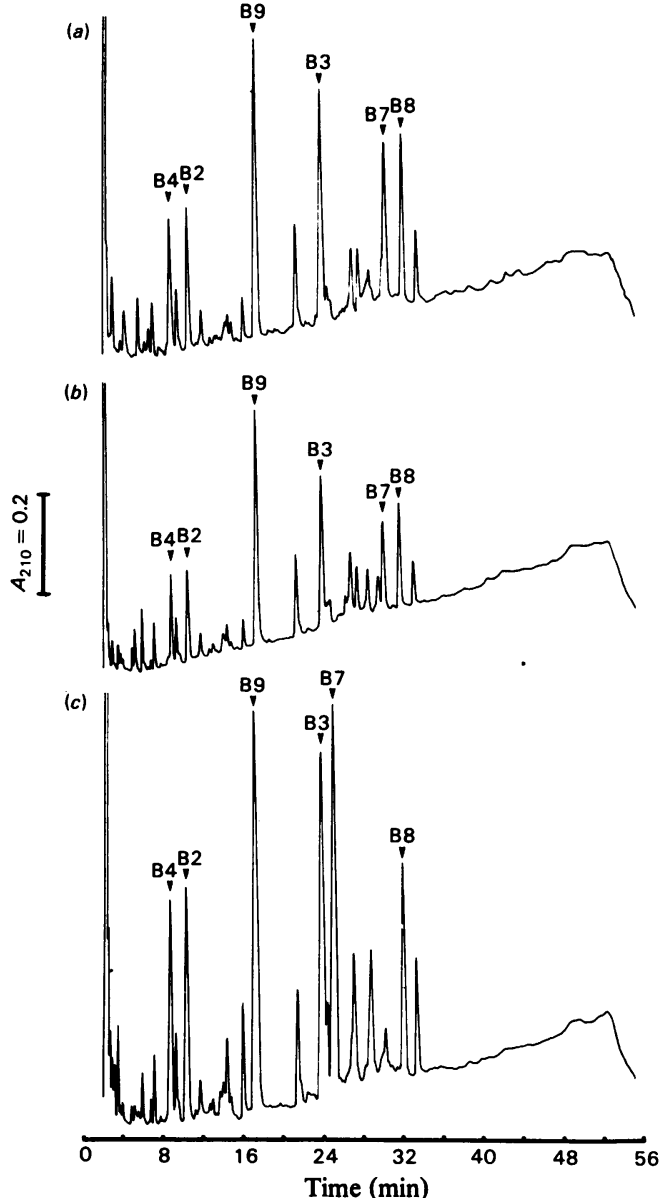

Fig. 2. High-pressure liquid chromatography of soluble fragments of the CNBr-treated c-subunits from strain AN955 (uncE410) (a), AN1781 (uncE501) (b) and $A N 1782\left(\right.$ unc $\left.^{+}\right)(c)$

The elution profile of the soluble $\mathrm{CNBr}$ fragments derived from the $c$-subunit from strain AN1892 (uncE502) was the same as that obtained for strain AN1781 (uncE501). The CNBr fragments indicated were identified after amino acid analysis. Experimental details are given in the Materials and methods section.

activities of membranes from the partial-revertant strains AN1781 (uncE501) and AN1892 (uncE502) were about twice the value obtained for membranes from strain AN955 (uncE410) (Table 3). The ATPase activities of the membranes from the partial-revertant strains could be about doubled by growing the cells on media containing succinate as energy source (Table 3). The phosphorylation rates and $\mathrm{P} / \mathrm{O}$ ratios obtained with membranes from the partial-revertant strains AN1781 (uncE501) and AN1892 (uncE502) were about $25 \%$ of the values
Table 2. Amino acid compositions of $\mathrm{CNBr}$ fragments $B 6$ and $B 7$ of the c-subunits from four strains of Escherichia coli

Amino acid compositions of the purified $\mathrm{CNBr}$ fragments were determined by using a Beckman System 6300 high-performance analyser after hydrolysis in $6 \mathrm{M}-\mathrm{HCl}$ for $22 \mathrm{~h}$. Leucine always analysed as seven residues in the B6 fragment of the $c$-subunit from normal strains. The numbers in parentheses are the numbers of residues expected for each fragment as calculated from the known amino acid sequence. The molar ratios were determined by dividing the concentrations of the amino acids derived from a particular fragment by the concentrations of an amino acid known to be in that fragment as a single residue.

\begin{tabular}{|c|c|c|c|c|c|}
\hline \multirow[b]{2}{*}{$\begin{array}{l}\text { Frag- } \\
\text { ment }\end{array}$} & \multirow[b]{2}{*}{$\begin{array}{c}\text { Amino } \\
\text { acid }\end{array}$} & \multicolumn{4}{|c|}{ Molar ratio } \\
\hline & & $\begin{array}{c}\text { AN1782 } \\
\left(\text { unc }^{+}\right)\end{array}$ & $\begin{array}{c}\text { AN955 } \\
\text { (uncE410) }\end{array}$ & $\begin{array}{c}\text { AN1781 } \\
(u n c E 501)\end{array}$ & $\begin{array}{c}\text { AN1892 } \\
\text { (uncE502) }\end{array}$ \\
\hline B7 & $\begin{array}{l}\text { Gly } \\
\text { Asp } \\
\text { Pro } \\
\text { Ala } \\
\text { Val } \\
\text { Ile } \\
\text { Leu }\end{array}$ & $\begin{array}{l}1.0(1) \\
1.2(1) \\
1.2(1) \\
1.0(1) \\
0.9(1) \\
1.0(1) \\
1.2(1)\end{array}$ & $\begin{array}{l}1.0 \\
1.0 \\
0 \\
1.0 \\
0.9 \\
0.9 \\
2.0\end{array}$ & $\begin{array}{l}1.0 \\
1.1 \\
0 \\
1.1 \\
1.1 \\
0.8 \\
2.0\end{array}$ & $\begin{array}{l}1.0 \\
1.3 \\
0 \\
1.3 \\
1.0 \\
0.9 \\
2.3\end{array}$ \\
\hline B6 & $\begin{array}{l}\text { Lys } \\
\text { Arg } \\
\text { Asp } \\
\text { Thr } \\
\text { Glu } \\
\text { Pro } \\
\text { Gly } \\
\text { Ala } \\
\text { Val } \\
\text { Ile } \\
\text { Leu } \\
\text { Phe }\end{array}$ & $\begin{array}{l}1.0(1) \\
1.7(2) \\
1.4(1) \\
1.1(1) \\
3.0(3) \\
2.1(2) \\
6.6(7) \\
6.0(6) \\
1.4(1) \\
5.7(6) \\
7.0(6) \\
2.7(3)\end{array}$ & $\begin{array}{l}1.0 \\
1.5 \\
1.5 \\
1.0 \\
2.9 \\
2.0 \\
6.8 \\
6.2 \\
1.5 \\
6.0 \\
7.2 \\
3.0\end{array}$ & $\begin{array}{l}1.0 \\
1.6 \\
1.5 \\
1.1 \\
2.9 \\
2.9 \\
7.2 \\
5.4 \\
1.5 \\
5.9 \\
7.4 \\
2.9\end{array}$ & $\begin{array}{l}1.0 \\
1.6 \\
1.4 \\
0.9 \\
2.7 \\
2.7 \\
7.1 \\
5.3 \\
1.6 \\
5.7 \\
7.4 \\
2.7\end{array}$ \\
\hline
\end{tabular}

obtained for normal membranes (Table 3). Membranes from strains AN1781 (uncE501) and AN1892 (uncE502) lacked ATP-dependent atebrinfluorescence-quenching activity (Fig. 3). NADHdependent atebrin-fluorescence-quenching activity was present in membranes from strains AN1781 (uncE501) and AN1892 (uncE502), and this activity was retained in membranes from which the $F_{1}$-ATPase was removed (Fig. 3).

Inhibition of ATPase activity on binding of the $F_{1}-A T P a s e$ to membranes from strain AN955 (uncE410)

The ATPase activity of membranes from strain AN955 (uncE410) was about 15\% of that obtained for normal membranes (see Table 3). However, on examination of these membranes by two-dimensional gel electrophoresis, it was clear that the five subunits of the $F_{1}$-ATPase were present in amounts at least equal to those found in normal membranes

Vol. 213 
Table 3. Growth yields and membrane properties of various strains of Escherichia coli

Growth yields were measured as turbidities (Klett units) after growth had ceased on media containing 5 mM-glucose. ATPase activities were determined on membrane preparations as described previously (Gibson et al., 1977a). Oxygen uptake by the membrane preparations was measured by using an oxygen electrode. ATP formed from ADP in the presence of $\left[{ }^{32} \mathrm{P}\right] \mathrm{P}_{1}$ was trapped as glucose 6-phosphate. The reaction was stopped by the addition of trichloroacetic acid and $P_{1}$ was extracted after the addition of molybdate.

\begin{tabular}{|c|c|c|c|c|c|}
\hline \multirow[b]{2}{*}{ Strain } & \multirow[b]{2}{*}{$\begin{array}{l}\text { Growth yields } \\
\text { (Klett units) }\end{array}$} & \multicolumn{2}{|c|}{ Activity } & \multirow[b]{2}{*}{$\begin{array}{l}\text { ATP formation } \\
\text { ( } \mu \mathrm{mol} / \mathrm{min} \text { per } \\
\mathrm{mg} \text { of protein) }\end{array}$} & \multirow[b]{2}{*}{$\mathrm{P} / \mathrm{O}$} \\
\hline & & $\begin{array}{c}\text { ATPase } \\
\text { ( } \mu \mathrm{mol} / \mathrm{min} \text { per } \\
\mathrm{mg} \text { of protein) }\end{array}$ & $\begin{array}{l}\text { NADH oxidase } \\
\text { (ng-atoms of } \mathrm{O} / \mathrm{min} \\
\text { per } \mathrm{mg} \text { of protein) }\end{array}$ & & \\
\hline AN1782 $\left(u n c^{+}\right)$ & 198 & 1.5 & 101 & 16.7 & 0.17 \\
\hline AN1781 (uncE501) & 160 & 0.42 & 149 & 5.4 & 0.04 \\
\hline AN1781 (uncE501)* & & 0.80 & 89 & 3.4 & 0.04 \\
\hline AN1892 (uncE502) & 158 & 0.44 & 152 & 4.9 & 0.03 \\
\hline AN1892 (uncE502)* & & 1.0 & 64 & 2.6 & 0.04 \\
\hline AN955 (uncE410) & 120 & 0.19 & 184 & $<0.1$ & $<0.001$ \\
\hline
\end{tabular}

* Membranes were prepared from cells grown on media containing succinate as energy source.

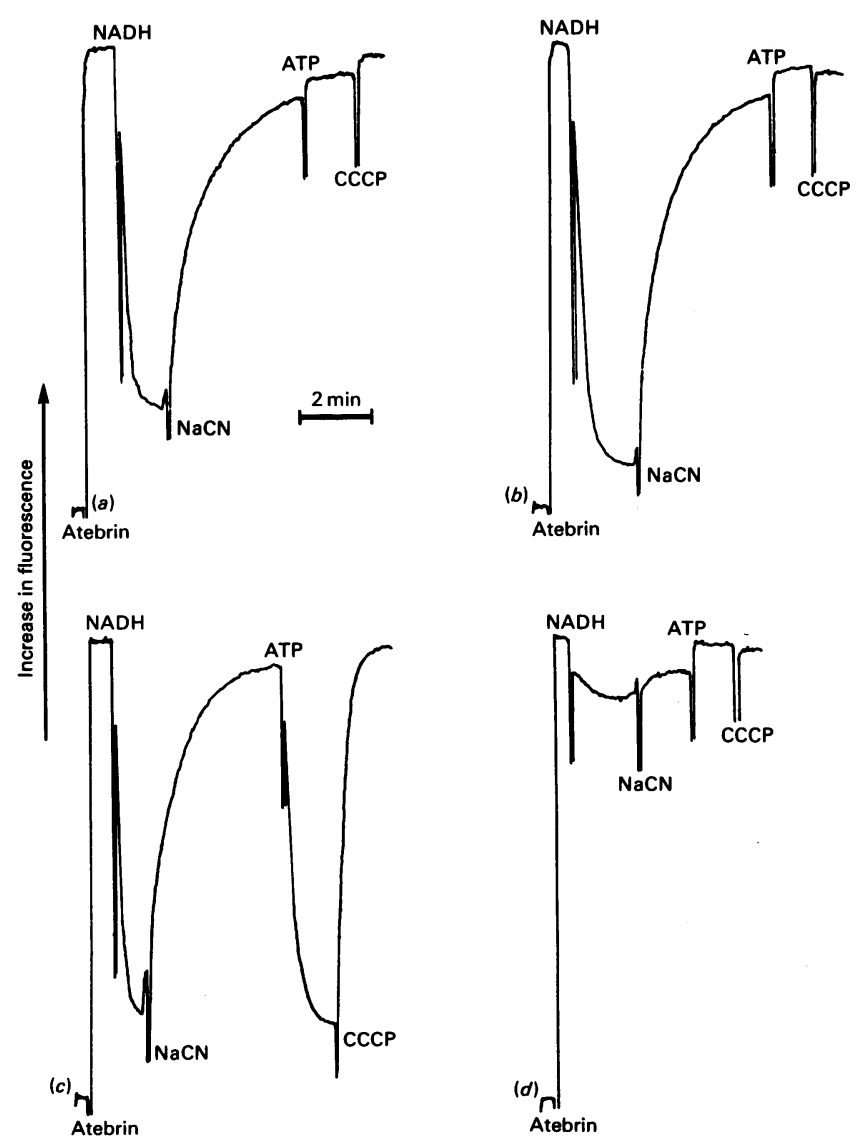

Fig. 3. Atebrin-fluorescence quenching in membranes prepared from strains AN1892 (uncE502) and AN1782 (unc ${ }^{+}$) Atebrin-fluorescence quenching was measured as described previously (Gibson et al., 1977a). Atebrin was added to give a final concentration of $4 \mu \mathrm{M}$, NADH to $2 \mathrm{~mm}, \mathrm{NaCN}$ to $2.5 \mathrm{~mm}$, ATP to $1 \mathrm{~mm}$ and carbonyl cyanide $m$-chlorophenylhydrazone (CCCP) to $20 \mu \mathrm{M}$. (a) Membranes from strain AN1892 (uncE502); (b) stripped membranes from strain AN1892 (uncE502); (c) membranes from strain AN1782 (unc $)^{+}$; (d) stripped membranes from strain AN1782 $\left(\right.$ unc $\left.^{+}\right)$. 


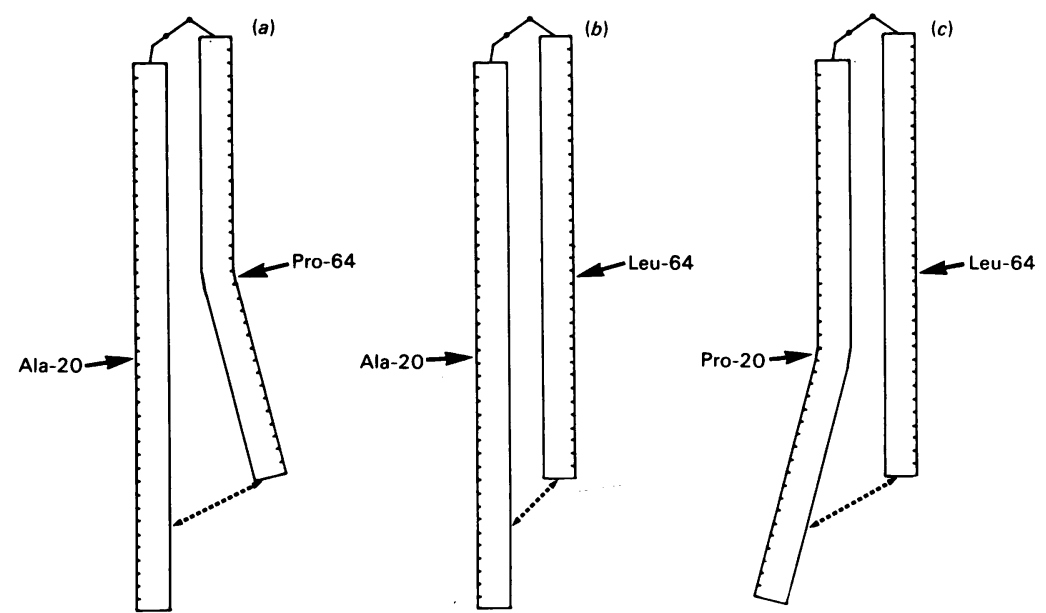

Fig. 4. Proposed structures of the membrane forms of the c-subunits of the $F_{1} F_{0}$-ATPase in mutant strains carrying the UncE 410 , uncE501 or uncE502 alleles

Structures are shown of the $c$-subunit in $(a)$ normal strains, $(b)$ strains carrying the $u n c E 410$ allele and $(c)$ partial revertant strains (derived from the uncE410 mutant strain) carrying either the uncE501 or uncE502 alleles. The changed amino acids are indicated. The broken line $(+\cdots)$ indicates the distance between the $C$-terminal alanine residue and the aspartic acid residue at position 7.

(G. B. Cox, unpublished work). A membrane preparation of strain AN955 (uncE410) was assayed for ATPase activity before and after dialysis against low-ionic-strength buffer in the absence of $p$-aminobenzamidine. Such treatment results in the dissociation of the $F_{1}$-ATPase from the membrane (Senior et al., 1979) and the ATPase activity of the membranes from strain AN955 (uncE410) increased from $0.19 \mu \mathrm{mol} / \mathrm{min}$ per $\mathrm{mg}$ of protein before dialysis to $0.94 \mu \mathrm{mol} / \mathrm{min}$ per $\mathrm{mg}$ of protein after dialysis. The ATPase activity of a normal membrane preparation was unchanged by this treatment. The activities are expressed per $\mathrm{mg}$ of membrane protein for purposes of comparison, as the ATPase activity is present in the supernatant after the membranes have been removed by centrifugation. A similar effect was found with membranes from strains AN1781 (uncE501) and AN1892 (uncE502), although the effect was not as marked, with the ATPase activities increasing from 0.40 $0.45 \mu \mathrm{mol} / \mathrm{min}$ per $\mathrm{mg}$ of protein before dialysis to $0.85-0.92 \mu \mathrm{mol} / \mathrm{min}$ per $\mathrm{mg}$ of protein after dialysis.

\section{Discussion}

The mutant allele uncE410 codes for a $c$-subunit of the $F_{1} F_{0}$-ATPase in which the proline at position 64 is replaced by leucine. The $\mathrm{G} \rightarrow \mathrm{T}$ base changes at both nucleotide 190 and nucleotide 191 provide an explanation for the difficulty experienced in isolating revertants (Downie et al., 1979b). CNBr fragment B7 of the $c$-subunit from the mutant strain AN955
(uncE410) contains two leucine residues and no proline residues, which is consistent with the DNA-sequencing data. Fragment B7 from the full-revertant strain AN1782 contains the expected one leucine and one proline residue. It is therefore clear that the uncoupled phenotype of strain AN955 (uncE410) is due to the substitition in the $c$-subunit of proline- 64 by leucine and may be attributed either to direct mechanistic effects or to indirect structural effects. The nature and position of the amino acid changes in the partial-revertant strains AN1781 (uncE501) and AN1892 (uncE502) would suggest the second of these alternatives.

We propose that, in the normal $c$-subunit of the $F_{1} F_{0}$-ATPase, a bend in the helix axis at proline- 64 (see Fig. 4) is required for the successful integration of this subunit with the other $\mathrm{F}_{0}$-subunits during the assembly in the membrane of the $F_{1} F_{0}$-ATPase. The distance between the $N$-terminal and $C$-terminal ends of the hairpin structure of the $c$-subunit would be different in the uncE410 mutant $c$-subunit (proline$64 \rightarrow$ leucine) as compared with a normal $c$-subunit (Fig. 4), and it is proposed that this would prevent the normal integration with the other $\mathrm{F}_{0}$-subunits. This incorrect assembly of the $c$-subunit into the $F_{0}$ structure could also provide an explanation for the observed inhibition of ATPase activity. It is the restoration, in the partial-revertant strains, of the distance between charged groups at the $C$-terminal and $N$-terminal ends of the $c$-subunit (see Fig. 4) that suggests that the phenotype of strain AN955 (uncE410) is due to the lack of normal integration of

Vol. 213 
the mutant $c$-subunit with the remaining $F_{0}$ subunits. The distance between a proline at position 64 and a proline at position 20 would also appear to preclude the direct involvement of proline in the mechanism of oxidative phosphorylation as an explanation for the phenotype of strain AN955 (uncE410).

The membranes of the partial-revertant strains do not have ATP-dependent atebrin-fluorescencequenching activity but are capable of carrying out oxidative phosphorylation. However, membranes from these partial-revertant strains retain NADHdependent atebrin-fluorescence-quenching activity after removal of the $F_{1}$-ATPase. The properties of membranes from the partial-revertant strains are therefore similar to those of membranes from mutant strains carrying either the uncE408 or uncE463 alleles in that apparently proton-impermeable membranes are capable of carrying out oxidative phosphorylation (Cox et al., 1983).

We thank Ms. D. Marsden, Mrs. B. Rowell and Mr. B. Webb for skilled technical assistance. Mr. D. Abigail is thanked for assistance with the growth of cells and preparation of membranes. A. E. S. is grateful for a grant from the National Science Foundation under the U.S./ Australian Co-operative Science Agreement.

\section{References}

Bachmann, B. J., Low, K. B. \& Taylor, A. L. (1976) Bacteriol. Rev. 40, 116-167

Cox, G. B., Newton, N. A., Gibson, F., Snoswell, A. M. \& Hamilton, J. A. (1970) Biochem. J. 117, 551-562

Cox, G. B. \& Gibson, F. (1974) Biochim. Biophys. Acta 346, 1-25

Cox, G. B., Gibson, F. \& McCann, L. (1973) Biochem. J. 134, 1015-1021

Cox, G. B., Jans, D. A., Gibson, F., Langman, L., Senior, A. E. \& Fimmel, A. L. (1983) Biochem. J. in the press

Downie, J. A., Gibson, F. \& Cox, G. B. (1979a) Annu. Rev. Biochem. 48, 103-131
Downie, J. A., Senior, A. E., Gibson, F. \& Cox, G. B. (1979b) J. Bacteriol. 137, 711-718

Downie, J. A., Langman, L., Cox, G. B., Yanofsky, C. \& Gibson, F. (1980) J. Bacteriol. 143, 8-17

Downie, J. A., Cox, G. B., Langman, L., Ash, G. R., Becker, M. \& Gibson, F. (1981) J. Bacteriol. 145, 200-210

Fillingame, R. H. (1976) J. Biol. Chem. 251, 6630-6637

Gay, N. J. \& Walker, J. E. (1981) Nucleic Acid Res. 9, 3919-3926

Gibson, F., Cox, G. B., Downie, J. A. \& Radik, J. (1977a) Biochem. J. 162, 665-670

Gibson, F., Cox, G. B., Downie, J. A. \& Radik, J. (1977b) Biochem. J. 164, 193-198

Gibson, F., Downie, J. A., Cox, G. B. \& Radik, J. (1978) J. Bacteriol. 134, 728-736

Graf, T. \& Sebald, W. (1978) FEBS Lett. 94, 218-222

Hoppe, J., Schairer, H. U. \& Sebald, W. (1980a) Eur.J. Biochem. 112, 17-24

Hoppe, J., Schairer, H. U. \& Sebald, W. (1980b) FEBS Lett. 109, 107-111

Hoppe, J., Schairer, H. U., Friedl, P. \& Sebald, W. (1982) FEBS Lett. 145, 21-24

Jans, D. A., Fimmel, A. L., Langman, L., James, L. B., Downie, J. A., Senior, A. E., Ash, G. R., Gibson, F. \& Cox, G. B. (1983) Biochem. J. 211, 717-726

Lowry, O. H., Rosebrough, N. J., Farr, A. L. \& Randall, R. J. (1951) J. Biol. Chem. 193, 265-275

Luria, S. E. \& Burrous, J. W. (1957) J. Bacteriol. 74, 461-476

Maxam, A. M. \& Gilbert, W. (1980) Methods Enzymol. $65,499-560$

Novick, R. P., Clowes, R. C., Cohen, S. N., Curtiss, R., Datta, N. \& Falkow, S. (1976) Bacteriol. Rev. 40, 168-189

Saito, H. \& Miura, K. (1963) Biochim. Biophys. Acta 72, 619-629

Selker, E., Brown, K. \& Yanofsky, C. (1977) J. Bacteriol. 129, 388-394

Senior, A. E., Fayle, D. R. H., Downie, J. A., Gibson, F. \& Cox, G. B. (1979) Biochem. J. 180, 111-118

Wachter, E., Schmid, R., Deckers, G. \& Alterndorf, K. (1980) FEBS Lett. 113, 265-270 